\title{
Health Education and Public Health
}

\author{
2021; 4(2): 393 - 410. doi: 10.31488/HEPH.161
}

\section{Review}

\section{State of Art: Cell Penetration and Cell-Penetrating Peptides and Proteins}

\section{Siegmund Reissmann}

Friedrich Schiller University, Faculty of Biological Sciences, Institute of Biochemistry and Biophysics, Dornburger Str. 25, 07743 Jena, Germany

Corresponding author: Siegmund Reissmann, Friedrich Schiller University,Faculty of Biological Sciences, Institute of Biochemistry and Biophysics, Dornburger Str. 25, 07743 Jena, Germany.

Received: May 01, 2021; Accepted: June 02, 2021; Published: June 04, 2021

\begin{abstract}
At recent time we live in Corona-Pandemic. The whole world needs vaccines and/or specific therapeutics against this new virus. In both cases compounds must be internalized either into antigen-producing cells or into infected cells. For vaccination with messenger ribonucleic acid, spike protein, and related protein fragments or an inactivated whole virus effective helper are required for their transport into cells. In the case of m-RNA the negatively charged molecule is surrounded by lipids and polymers. In the case of spike proteins adenoviral vectors were used. Thus, also the recent pandemic situation shows us the important role of easy cell penetration. Cell-penetrating peptides (CPPs) are very effective at transporting peptides, proteins, and hydrophilic bioactive synthetic or natural compounds, including herbal products, too. They are also able to transport ribonucleic acids and their chemical derivatives such as peptide nucleic acids and morpholino oligomers. This review discusses the state of the art in preclinical studies and clinical trials with cell-penetrating peptides. While CPPs from first generation exhibit only low cell and tissue selectivity, the peptides from the newer generation are characterized by distinct selectivity for tumor cells. Certain CPPs show an innate, high affinity for cancer cells and were successfully tested for transporting drugs into tumors. Aiming to enhance cell and tissue selectivity, specific properties of tumor cells and tumor microenvironments can be used, such as certain tumor-cell-specific proteases, fenestrated capillaries, low pH-value, or hypoxia. Because CPPs are able to penetrate barriers such as the blood-brain barrier, skin, mucosa and conjunctiva of the eye, they are able to avoid administration of drugs by painful injections with needles. Transport of drugs through blood-brain barrier opens possibilities to treat glioblastomas and such brain diseases as Alzheimer and Parkinson. In addition to internalization of drugs, also the imaging of tumors, metastases and inflamed tissue remains an important field for the application of CPPs. For diagnostic use, CPPs can be coupled to sensitive markers, such as NIR-fluorescence markers, NMRsensitive Gd-complexes or radionuclides. Imaging with cell-selective and labeled CPPs enables not only the detection of tumors, metastases, thrombosis, or inflammation but also the complete removal of diseased tissue by guided surgery. Conjugation to polymers or nanoparticles stabilizes CPPs against proteolytic degradation, improves handling and enables coupling of additional targeting molecules, which can greatly enhance the selectivity for diseased tissue. Such multifunctional pharmacological nanoparticles have been very promising in clinical trials. The ideal construct, the endpoint of this development, would be a self-navigating carrier system for intracellular drug delivery. Besides CPPs a variety of other methods can facilitate transport of cargoes and labels into live cells. These chemical, electrical, mechanical, and viral methods are shortly discussed at the end of the article and compared to CPPs regarding their advantages and disadvantages.
\end{abstract}

Keywords: Penetration of live cells, cell-penetrating peptides, structural types of CPPs, cell- selectivity, subcellular localization, penetration of barriers, biodistribution, conjugation to nanoparticles.

\section{Cell Penetration and Cell-Penetrating Peptides and Proteins}

\section{Definition}

Cell-penetrating peptides and proteins (CPPs) are compounds which can penetrate live cells and can transport cargoes and labels into the cell or even into subcellular organelles. Some cells are easy to transduce or to transfect, other cells only difficult or not to transfect. Uptake efficiency can strongly depend on CPP, on the cargo, cell type and used conditions. CPPs are very effective in transporting peptides, proteins, hydrophilic bioactive synthetic or natural compounds. Furthermore, they are tools for transporting drugs, including herbal products from classical chine's medicine. CPPs are also able to transport ribonucleic acids and derivatives of them like peptide nucleic acids or morpholino oligomers. CPPs are also able to penetrate barriers like blood-brain barrier, conjunctiva of eye, skin, 
epithelial tissue, and intestinal mucosa. As membrane-active peptides some of them can kill microorganisms directly or can transport effective antimicrobial drugs into infected cells.

\section{History}

First Cell-penetrating peptides (CPPs) were described about 30 years ago. Till now more than 9,000 publications appeared, and more than 800 peptides are described. The number of yearly publications about CPPs has remained constant at a high level, about 800 in each of the last years. The number of patent applications is rapidly growing. Obviously a too large number of reviews have been published, summarizing the expected multifold possibilities for future application in the clinic. From this large number of reviews here are only very recent and corresponding reviews are recommended [1-5].

Nevertheless, of the intensive research in this field a highly effective and selective internalization of drugs and imaging labels into live cells, especially into all cell-types, remains till now challenging. Thus, till now no one CPP is approved by Food and Drug Administration (FDA) as a drug. But it seems that the CPPs are more promising and convenient for clinical use than chemical detergents, electrical or mechanical penetration methods, and in certain cases also as viral vectors.

\section{First and Next Generations \\ First Generation}

The firstly described cell-penetrating peptides were a substance P analog [6], HIV-TAT (47-57) derived from TAT-protein of virus HIV-1 [7] and penetratin, a peptide derived from Drosophila antennapedia gene homeobox [8]. Many groups from all over the world aimed to find new structures with enhanced internalization efficiency. Table 1 lists names, and origins of CPPs, which are classified by structural types. The Table shows, that many CPPs are derived from viral proteins, from venoms or other natural products. Some CPPs, like the series of MPG- and PepFect-peptides are designed on the basis of detected natural penetrating sequences.

\section{New Generation}

While CPPs from first generation exhibit mostly only a low cell- and tissue-selectivity, the peptides from the newer generation are characterized by distinct selectivity for certain cell types, especially for tumor cells. Aiming to enhance cell- and tissue-selectivity specific properties of tumor cells and tumor environment can be used such as fenestrated capillaries, low $\mathrm{pH}$-value, or hypoxia. Thus, some CPPs form their active CPP-conformation only under these conditions. One of the very important contributions in the field of tissue selectivity was the development of activatable CPPs [9]. In the inactive state these peptides are closed like a Swiss army pocketknife (Figure 1) and can be opened by activators e.g., certain tumor-cell specific proteases or under hypoxic conditions. Additionally, an external activation can be performed, for instance with photo-activatable CPPs using an UV- or IR-irradiation focused on target [10].

\section{Structural Types}

CPPs can be classified and sub-classified by different viewpoints. Depending on their sequence they can be divided into cationic, amphipathic, hydrophobic, and acidic peptides.
Shortest CPPs consist of 5 amino acids; the longest transporters are fusion proteins with more than hundred amino acids.

Among the CPPs from the first and from newer generation are many lysine- and arginine-rich cationic peptides. These cationic CPPs are able to form non-covalent complexes with nucleic acids but they require in most cases a covalent conjugation to proteins, marker molecules or drugs [11]. Their positive charges favor the interaction with negatively charged components in the cell membrane and in the plasma. But, by interaction with blood plasma these CPPs are prone to be rapidly eliminated by reticulo-endothelial system.

Also, amphiphilic, and acidic CPPs were intensively studied. Thus, amphipathic peptides like MPG-peptides were applied for different preclinical and clinical studies. Hydrophobic peptides are rich on such hydrophobic amino acids like leucine, valine, and tryptophane. Acidic fragments from the bacterial enzyme cupredoxin, mainly fragments $\mathrm{p} 18$ and $\mathrm{p} 28$ of azurin, exhibit distinctive affinity to tumor cells and have high potential for clinical application. [12].

Many peptides from the new generation are derived from venoms of amphibian, snakes, and insects. In Table 2 properties and applications are listed for some new CPPs selected from the literature of the last years. Please accept that the selection is my very personally point of view.

\section{Cationic CPPs \\ HIV-TAT}

From TAT-protein of virus HIV-1 [7] various sequences were derived and tested for their uptake efficiency. Commonly used is the sequence HIV-TAT (47-57).

\section{Penetratin}

Penetratin is a penetrating peptide derived from Drosophila antennapedia gene homeobox [8].

\section{Protamine}

An old protein and the newly developed low-molecular-weight protamine (LMWP) and derivatives.

Long time before discovery of CPPs, complexes containing protamine derivatives were used to transport insulin, interferon, glucagon-like peptide, or somatostatin. Because this heterogeneous group of peptides evoked many undesired side effects during clinical trials, Byun et al. [13] developed a short-chained low-molecular-weight protamine, abbreviated LMWP. The sequence of this peptide contains a compact region of arginine residues. LMWP helps to target drug resistant breast cancer and enables drug delivery to the brain via intranasal administration.

\section{Crotamine}

Crotamine is the peptide component of the venom from the South American rattlesnake, Crotalus durissus terrificus. Its amino acid sequence contains 42 residues, linked by three disulfide bridges [14]. In most publications about application, a structurally minimized sequence was described with a deletion from positions 10 to 37, thus combining residues $1-9$ with residues $38-42$ to form 4-Ser-crotamine( $\Delta 10-37)$. This designed peptide was also named nucleolar targeting peptide (NrTP), due to its preferential accumulation in the nucleoli of cells [15]. The ability of crotamine to transport cargoes into actively proliferating cells [16], makes crotamine and its derivatives suitable markers 
Table 1. Selected peptides from the First Generation.

\begin{tabular}{|c|c|l|}
\hline \multicolumn{3}{|c|}{ Structural Characterization } \\
\hline \multicolumn{3}{|c|}{ Cationic Peptides } \\
\hline 2 & Penetratin & Drosophila antennapedia gene homeobox \\
\hline 4 & HIV-TAT(47-57) & TAT-protein of virus HIV-1, sequence 47-57 \\
\hline 5 & Vligo-arginines & $\begin{array}{l}\text { Herpes simplex virus transcription factor } \\
267-300\end{array}$ \\
\hline \multicolumn{3}{|c|}{ Amphiphatic Peptides } \\
\hline 5 & MPG-peptides & $\begin{array}{l}\text { Designed: sequence of HIV-protein gp4 fused } \\
\text { to NLS }\end{array}$ \\
\hline 6 & Transportan & Chimeric Galanin/mastoporan 10-mer \\
\hline & KLA-sequences & \\
\hline & pVEC & Vascular endothelial cadherin \\
\hline \multicolumn{3}{|c|}{ Hydrophobic Peptides } \\
\hline 7 & Caiiman crocodylus & Signal sequence of light chain \\
\hline 8 & Integrin $\beta 3$-fragment & Tumor homing \\
\hline & hCT(9-32)-br & Sequence from human calcitonin \\
\hline \multicolumn{5}{|c|}{ Acidic Peptides } \\
\hline 9 & SAPE & Amphipathic negative CPP \\
\hline 10 & Poly(glutamic acid) & Negative charged polymer \\
\hline \multicolumn{3}{|c|}{} \\
\hline
\end{tabular}

\section{Maurocalcine}

Maurocalcine was first isolated from the Tunisian scorpion Scorpio maurus palmatus. Full-length maurocalcine is a 33mer basic peptide cross-linked by three disulfide bridges [17]. Numerous analogs have been derived by simultaneous internal cysteine replacement with 2-aminobutyric acid (Abu) and sequence truncation [18]. Fragment 1-9, which corresponds to the hydrophobic surface, is called mini-maurocalcine. Gold nanoparticles containing a maurocalcine-analog allow biomedical imaging of cancer cells.

\section{Buforins}

Buforins are firstly isolated from Asian toad Bufo bufo gargarizans. Buforin I contains 39 amino acid residues, buforin II is a 21-mer peptide [19]. Both buforins show complete sequence homology with the N-terminal region of histone H2A. It is assumed that they are formed in the stomach of toads by proteolytic cleavage of H2A with pepsin. They are potent antimicrobial peptides; they also exhibit anti-cancer activities [20]. They do not exhibit cytotoxic activity against several eukaryotic cells and are nearly non-hemolytic in respect to human erythrocytes. These properties make the buforin-peptides attractive for pharmaceutical applications.

\section{Nucleus-Penetrating Peptide Penetrating Peptide CB5005}

CB5005 is a rationally designed peptide containing a cell-permeable sequence cascading to a NF-kB nuclear localization sequence. This peptide can penetrate the brain, owing to its unique affinity for brain endothelial cells, accumulate at the tumor site, and infiltrate deeply into tumor spheroids [21]. Interestingly, CB5005 not only penetrates cells but also enters their nuclei, thereby displaying some potential in the treatment of glioblastomas. Indeed, CB5005 functions simultaneously as a CPP and

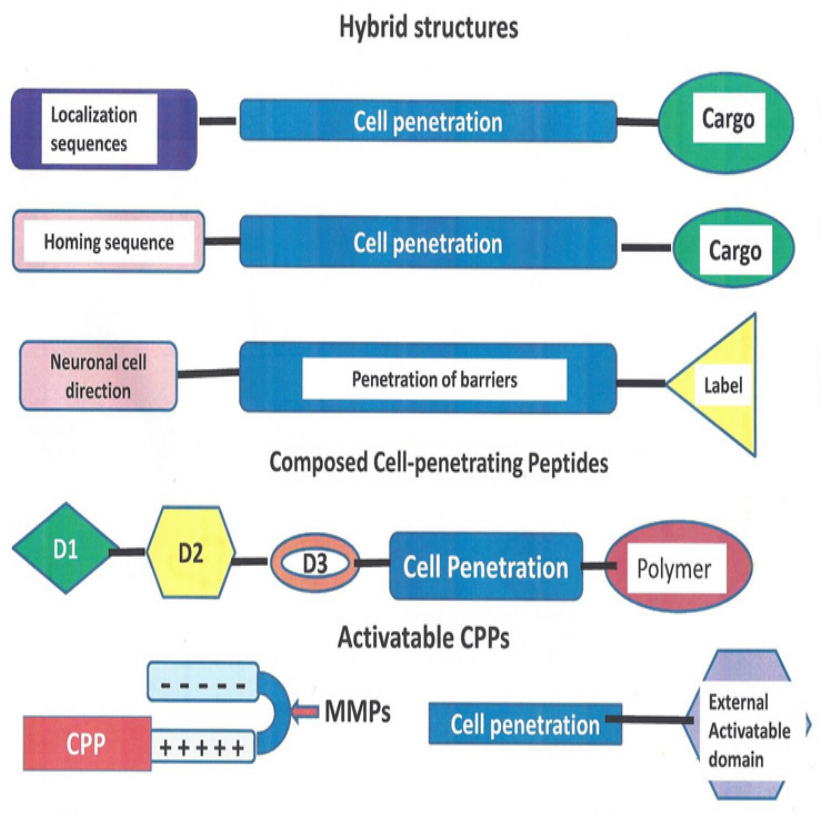

Figure 1. Hybrid or composed structures and activatable CPPs.

D1,D2,D3: domains for endosomal leakage, homing, subcellular localization, tissue selectivity.

as a tumor growth inhibitor.

\section{Antimicrobial peptide cathelicidin: sC18}

Cationic antimicrobial peptides (AMPs) are present in all living organisms. They can inactivate bacterial or viral pathogens by permeabilizing their membranes. The CAMP cathelicidin (CAP18) binds to lipopolysaccharides. Neundorf at coworker [22) found that the peptide fragment $\mathrm{sC} 18$ fulfills all requirements for a good CPP: It facilitates internalization of cargo into living cells with high transduction rates and efficiencies. The peptide $\mathrm{sC} 18$ shows no cytotoxic effects.

\section{Buffalo cathelicidin family}

Members of the newly identified buffalo-derived cathelicidin (CAT) family exhibit preferential binding to multiple tumor cell lines. Additionally, they show higher translocation efficiency than most other CPPs. Therefore, CAT is considered as a novel tumor homing CPP with great potential for selective drug delivery [23].

\section{Spider toxin Lycosin-I}

Similar to venoms from snakes and scorpions, toxins from spiders contain peptides with cell-penetrating properties and high affinity to cancer cells. For example, lycosin-I, a toxin from the spider Lycosa singoriensis, interacts selectively with breast and prostate cancer cells. When conjugated to spherical gold nanoparticles, lycosin-I exhibits selective intracellular translocation towards cancer cells and display an unprecedented low selectivity over noncancerous cells. Moreover, the conjugate to gold nanoparticles shows an efficient photothermal effect under near infrared irradiation, leading to the killing of cancer cells in vivo [24].

\section{Amphiphilic Peptides \\ PepFect series}


Table 2. Cell-penetrating peptides from the New Generation.

\begin{tabular}{|c|c|c|}
\hline \multicolumn{3}{|r|}{ CATIONIC CPPS } \\
\hline \multicolumn{3}{|r|}{ HIV-TAT } \\
\hline 1 & HIV-TAT(47-57) & YGRKKRRQRRR-amide \\
\hline 2 & Cys-[HIV-TAT(47-56;r,R)] & C-YGRrRrRQRrR-amide \\
\hline 3 & $(\mathrm{rR})_{3} \mathrm{RR}$ & rRrRrRRR \\
\hline \multicolumn{3}{|r|}{ Protamine } \\
\hline 4 & Protamine & Family of heterogeneous polycationic peptides, $\mathrm{Mw} \approx 4500 \mathrm{Da}$ \\
\hline 5 & $\begin{array}{l}\text { Low molecular weight Protamine } \\
\text { (LMWP) }\end{array}$ & VSRRRRRRGGRRRR \\
\hline \multicolumn{3}{|r|}{ Crotamine } \\
\hline 6 & Crotamine & $\begin{array}{l}42 \text { amino acid residues with } 3 \text { disulfide bonds: } \\
\mathrm{C}_{4}-\mathrm{C}_{36}, \mathrm{C}_{11}-\mathrm{C}_{30}, \mathrm{C}_{18}-\mathrm{C}_{37} \text { YKQCHKKGGHCFPKEKICLPPSSDFGKMDCRWR- } \\
\text { WKCCKKGSG }\end{array}$ \\
\hline 7 & [4-Ser-Crotamine $(\Delta 10$ to 37$)]$ & YKQSHKKGGKKGSG-amide \\
\hline \multicolumn{3}{|r|}{ Buforins } \\
\hline 8 & Buforin I, II, IIb & 39 and 21-mer peptide with $\mathrm{N}$-terminal region of histone $\mathrm{H} 2 \mathrm{~A}$ \\
\hline 9 & Buforin II (BR2) & RAGLQFPVGRLLRRLLR \\
\hline \multicolumn{3}{|r|}{ Peptide CB5005 } \\
\hline 10 & CB5005 (Activation of NF- $\mathbf{s}$ ) & KLKLALALALAVQRKRQKLMP \\
\hline \multicolumn{3}{|r|}{ Guanidine-rich carrier } \\
\hline 13 & Guanidine-rich carrier & D-Sorbitol-with 8 guanido moieties at an arm at position 3 . \\
\hline \multicolumn{3}{|r|}{ Maurocalcine } \\
\hline 14 & Maurocalcine & $\begin{array}{l}\text { 33-mer basic peptide with } 3 \text { disulfide bridges: } \\
\left(\mathrm{C}_{3}-\mathrm{C}_{17}, \mathrm{C}_{10}-\mathrm{C}_{21}, \mathrm{C}_{16}-\mathrm{C}_{32}\right) \\
\text { GDCLPHLKLCKENKDCCSKKCKRRGTNIEKRCR }\end{array}$ \\
\hline 15 & 3-Abu-Maurocalcine(1-9) & GD(Abu)LPHLKL-amide \\
\hline 16 & MCA-UF14-25 & KD(Abu)-(Abu)SKK(Abu)KRRG-amide \\
\hline \multicolumn{3}{|r|}{ ACIDIC CPP } \\
\hline \multicolumn{3}{|r|}{ Azurin } \\
\hline 17 & Azurin & Cupredoxin, secretad by Pseudomonas aeroginosa; $\mathrm{Mw} \approx 16,000 \mathrm{Da}$ \\
\hline 18 & Azurin p18 (Fragment 50-67) & LSTAADMQGVVTDMGASG-amide \\
\hline 19 & Azurin p28 (Fragment 50-77) & LSTAADMQGVVTDMGASGLDKDYLKPDD-amide \\
\hline 20 & Azurin C-terminal Fragment 88-113, & GSGEKDSVTFDVSKLKEGEQYMFFCT \\
\hline 21 & Azurin C-terminal Fragment 96-113 & TFDVSKLKEGEQYMFFCT \\
\hline \multicolumn{3}{|r|}{ FUSION PROTEINS } \\
\hline \multicolumn{3}{|r|}{ Bindin } \\
\hline 23 & Bindin B18 & LGLLLRHLRHHSNLLANI \\
\hline 24 & Bindin B55 & $\begin{array}{l}\text { KAVLGATKIDLPVDINDPYDLGLLLRHLRHHSNLLANIGDPAVREQVL- } \\
\text { SAMQEEE }\end{array}$ \\
\hline \multicolumn{3}{|r|}{ RDP-Peptide } \\
\hline 25 & RDP-peptide & KSVRTWNEIIPSKGCLRVGGRCHPHVNGGGRRRRRRRRR \\
\hline \multicolumn{3}{|r|}{ Elastin like peptides } \\
\hline 26 & Elastin like peptides & $\begin{array}{l}\text { Val-Pro-Gly-Xaa-Gly pentapeptide repeated } 120 \text { times. } \\
\text { Xaa:any amino acid without Pro. }\end{array}$ \\
\hline
\end{tabular}


of actively proliferating cells, such as breast-cancer cells, and makes it to potential drug transporters.

Ülo Langel and his research group made many important contributions to the development of effective and selective CPPs $[25,26]$. In particular, this group created a series of PepFect peptides, derived from the $\mathrm{N}$-terminal sequence of galanin aiming to transport different types of ribonucleic acids and mimics of them; to ameliorate tissue- or barrier-specific internalization; and to enhance proteolytic stability. For this purpose, certain proteinogenic amino acids were replaced by non-proteinogenic ornithine.

\section{MPG-Peptides}

The French research group in Mont Pellier developed a series of designed peptides for transport of different cargoes via formation of non-covalent complexes [27,28]. The amphipathic basic sequences are derived from a fusion sequence of HIV protein gp41, a hydrophilic lysine-rich nuclear localization sequence, and a spacer.

\section{Hydrophobic CPPs}

To the group of hydrophobic CPPs belong such peptides like Kaposis sarcoma fibroblast growth factor [29], integrin $\beta 3$-fragment [30] or human calcitonin partial sequence 9-32 [31]. They are mostly partial sequences of functional proteins e.g. translocation sequences and can effectively transport cargoes through interaction with receptor proteins or membrane lipids.

\section{Acidic Sequences Azurin}

Azurin is a 128-amino acid-long bacterial protein. It belongs to the cell-penetrating peptides and simultaneously inhibits multiple tumor-promoting pathways [12,32,33]. Azurin preferentially enters cancer cells, where it exerts cytostatic and cytotoxic (apoptotic) effects with no side effects for normal cells [34]. Like other newly developed CPPs azurin can directly kill tumor cells by influencing specific signaling pathways. For instance, Bernardes et al. [35] reported that azurin exerts anticancer activity by interacting with multiple targets and interfering with multiple steps of tumor progression. In a firstin-class, first-in-human clinical trials, the azurin peptide p28 has been shown to display very little toxicity and high antitumor activity in many advanced-stage cancer patients [36]. The C-terminal sequences 96 to 113 show structural similarity to a ligand known as ephrin B2 and bind to the corresponding receptor who's signaling is involved in cancer progression. Thus, azurin and its C-terminal fragments can also contribute to cancer cell growth inhibition [37]. Azurin enhances additionally the sensitivity of tumor cells to various chemotherapeutics [38].

\section{Cell-Penetrating Peptides and Proteins with Specific Functional Properties}

In the last decade certain new peptides were published focused on enhancing transport efficacy, most importantly escaping from endosomes, and selectively transporting into target cells.

\section{Endosomal leakage structures}

After discovering effective CPPs it became very important to improve their sequences aiming avoiding endosomal entrapment or triggering endosomal escape. One way was developing peptides with alternating chirality of amino acid residues. Thus such cationic peptides like HIV-TAT(47-57) and octa-arginine with alternating chirality of arginine residues were released from endosomes into cytosol [39]. This effect is due to changed conformation and changed conformational flexibility. Anionic peptides azurin p28 and p18 with changed chirality of certain amino acids can escape from endosomes, too [40]. Very interestingly, also for many cyclic CPPs a release from or avoiding entrapment in endosomes was demonstrated [41].

\section{Transduction and transfection of difficult to transfect cells}

The last years also clearly showed a new problem, the transduction and transfection of difficult to transfect cells. This problem is especially of interest in respect to clinical application. To the hardly to transfect human cells belong inter alia, stem cells [26,42], primary cells (e.g. human fibroblasts, hematopoietic cells, mast cells [43], natural killer cells [44] and also macrophages [45]. Nevertheless, only very few authors have focused their research on such hardly to transfect cells. We detected a large difference between internalization of peptides and proteins conjugated to fluorescent markers or complexed with drugs on the one hand and linear and cyclic DNA on the other hand. In our hand's proteins, also very large proteins could be easily transported with CPPs, even into difficult to transfect cells $[42,46]$. Thus, non-covalent complexes formed from amphipathic CPPs and proteins could be easily transported into such difficult to transfect cells like Kasumi-cells and Leishmanias [11,42]. On the other side we were unable to deliver plasmids into the same cells by approaching the use of a variety of different CPPs [46]

Transduction and transfection of difficult-to-transfect cells seems to require rationally designed hybrid peptides, examples will be described in chapter. Composed peptides can promote the delivery of very large cargo proteins like CRISPR-Cas9 and -Cpfl ribonucleoproteins into hardly to transfect human T-cell-derived Jurkat cells and primary NK cells [42]. Thus, enabling the use of the very promising CRISPR recombinant proteins for therapeutic approaches, such as gene editing.

\section{Stabilization against proteolytic degradation}

Since peptides can be degraded by many different proteases in the skin, blood, intestinal tract, organs, and tissues, CPPs should be stabilized against enzymatic degradation. For this reason, their N- and C-terminus or peptide backbone can be modified by fatty acylation or amidylation [25,47], and certain amino acid residues in their sequence can be replaced by residues in D configuration [39], by non-proteinogenic amino acids and moieties [25] or by cyclization [48]. Conjugation to polymers, dendrimers and nanoparticles reduces proteolytic cleavage, too.

\section{Composed Structures}

Very complex considerations must be performed to design a drug. Thus, we have to keep in mind that a drug must be administrated, it has to be transported in the blood with tight contact to different blood cells and serum proteases, it has to escape from the vascular system at the right place and to penetrate into the target tissue. Finally, in that tissue the CPP must transport the drug into the target cell through the cell membrane. The transport should be fast, selective, and effec- 
tive. Inside the cell the drug must be transported either to the cytosol or to target subcellular organelles with help of localization sequences. All these requirements together can in many cases not be combined in only one single molecule; they require finally the development of multifunctional nano-carriers.

\section{Avoiding endosomal entrapment or triggering endosomal escape}

Endosomal leakage domains such as CM18 can be fused to the sequence of penetrating peptides. The sequence of CM18 derives from the hydrophilic N-terminal sequence (1-7) of cecropin A, combined with the N-terminal sequence (2-12) of melittin. The hybrid peptide (His)6-CM18-PTD4 is composed of a hexa-histidine fused to the endosomolytic peptide CM18 and the protein transduction domain PTD4. Within a short co-incubation time, it can form non-covalent complexes with very large functionally active proteins. This rationally designed peptide triggers not only endosomal escape but also promotes the delivery of cargo proteins into difficult-to-transfect cells [42].

\section{Peptides with intrinsic endosomal release activity}

Peptide B18 represents the "minimal membrane-binding and fusogenic motif" of bindin. Both bindin peptides, B18 and B55 respectively, can self-assemble in lipid bilayers and transport biomacromolecules not only into cytosol, they perform also nuclear translocation [49].

\section{Cell- and Tissue-selectivity Tumor-selectivity}

Peptides from the first generation have mainly low tissue selectivity. It means that cargoes are transported into nearly all celland tissue types, except into hardly to transfect cells. Selectivity is due to interaction with surface receptors. The new generation is characterized by higher cell specificity and higher tissue selectivity, too. By some single peptides like azurin, crotamine, buforins, cathelicdine, CB5005, and Lycosin-1 the cell specificity is an innate property. In most other cases composed CPPs or single CPPs bound to multifunctional nanoparticles achieve a high selectivity by combining different affinities to cell surface or tissue. Thus, insertion of homing sequences can guide the translocation of the $\mathrm{CPP}$ with its cargo from vessels to the target tissue [50]. Application of specific ligands from the family of integrin-receptors also enables a selective therapy of such tumours which have a high occurrence of corresponding integrin-receptors on their cell-surface. [50]. Moreover, to introduce or enhance target selectivity, activatable CPPs can be rationally designed. Their activation can be triggered by cell-specific proteases e.g. tumor-specific proteases such as matrix metalloproteinase [9], fibroblast activation protein [FAB] [51], or lower $\mathrm{pH}$ values than those found in healthy tissues [52], or under hypoxic tissue conditions [53].

\section{Selectivity for neuronal cells}

Rabies virus glycoprotein (RVG) is the only known protein component that interacts specifically with neuronal cells. The nerve-binding region was partially taken from the residues 189214 and 330-357 of the glycoprotein RVG, which guide viral entry into neuronal cells. Thus, the recombinant fusion product RDP consists of 39 amino acids derived from the fused RVG with a nona-arginine residue at the $\mathrm{C}$ terminus. Thus, the protein RDP enables the delivery of fused proteins into neuronal cells, such as the glial cells. Notably, this fusion protein exhibits a neu- roprotective effect in Parkinson's disease animal models [54].

\section{Transport through multilayer tissue}

Aiming treatment of diseases, the applied conjugates or complexes of CPP and cargo must deeply penetrate into diseased tissue, e.g. cancer tissue. This requirement has to be studied in 3-D-models [55].

\section{Transport into subcellular organelles}

In contrast to some till now unsolved problems, the cell- and tissue-selectivity could be strongly enhanced with newer generations of CPPs. Even a directed transport into functional important subcellular organelles such as nucleus, nucleolus, cytosol, mitochondria, lysosomes, Golgi apparatus, or endoplasmic reticulum could be achieved. For clinical application of CPPs are important especially nuclear and mitochondrial localization sequences. Mitochondria Penetrating Peptides (MPPs) opens the possibility of treating mitochondria evoked diseases [56]. CPPs with nuclear localization sequences are important for gene therapy [15].

\section{External triggered cargo delivery}

Elastin-like peptides (ELPs) are bioengineered and biocompatible proteins that, when conjugated to CPPs, can act as carriers for delivery of therapeutic peptides with temperature-dependent properties. ELPs undergo temperature-dependent inverse phase transition [57] and accumulate in tumors upon exposure to externally focused heat $\left(40-42^{\circ} \mathrm{C}\right)$.

\section{Administration and Biodistribution}

Administration of CPPs, free or conjugated to polymers, dendrimers and nanoparticles can be performed in different ways. The literature describes besides oral application also inhalation, nasal-, intestinal-, parenteral- or endothelial-administration as well as intravenous and intraperitoneal injection. Time-dependent distribution studies of CPP and cargo in the whole body, the so-called Pharmacodynamic studies, are a prerequisite for clinical trials and it is recommended to start with these studies in a very early stage of research.

Furthermore, for clinical use it is important to avoid toxic reactions in any organ, also outside the target organ. Thus Qiu et al. [58] studied the induction of apoptosis and necrosis by some CPPs on normal human liver cells. The kidney viability due to possible accumulation, also the elimination through and influence on kidneys has to be estimated for candidates which are chosen for clinical application. A critical view of related publications shows that only few publications contain such recommended studies about biodistribution. While in first two decades in the history of CPPs mainly studies on internalization and transport of cargoes into cell cultures were published in the recent research quite more pharmacodynamic and pharmacokinetic studies on animals are performed.

In general, aiming to enhance concentration at target organ and to avoid toxic side actions on other organs the kind of administration should be chosen, if necessary, topically or by injection. Selectivity of targeting, especially to tumor tissue, can be enhanced by coupling to polymers or nanoparticles via extravagation through leaky capillaries of this tissue. Thus, for targeting lymphatic tumor is recommended the use of homing sequences. Additionally, selectivity can be enhanced by combination with targeting ligands in response to specific properties of tumor cells or by external photo- or thermally activation. 
Table 3. Polymers, dendrimers, liposomes and nanocarriers used for conjugation.
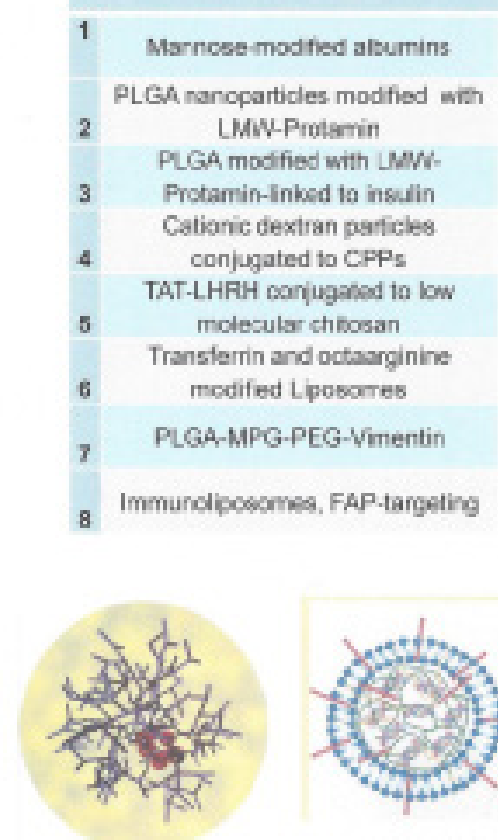

Polymer, Dendrimer

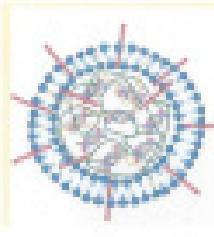

Liposom, Lipid Nanoparticle

Brain cancer
Breast cancer
Distetes
Chranic hepatits 8
Heqabcoelular
Carci norra
Ovarian canoer
Cervices cancer
Breast cancer

Dual targeting transport of Damrubicin into brain tumor

Overcoming drug resistance

Oral bioswailabity of insaln, intastival abearption

Treatment with irtemalibed peptide muckic aods (PNA)

Gene transport into hepatocelula cercinoma cells

Intracelular DOX delivery

Enhanced ustake of PL GA-medifed raneparticken

Imaging of spontanecus metastases
Poly-amino acids and Proteins

Polyethylene glycol PEG

Poly(lactic-co-glycolic acid) PLGA

Polyethylene-imine PEI

Dextran's

Chitosan's

Brush polymers $\mathrm{POX}$

Combined Polymers

Liposomes (LPS)

Nano-Particles (NPs)

Table 4. Application of CPPs in diagnostic and surgery.

\begin{tabular}{|c|c|c|c|}
\hline \multicolumn{2}{|c|}{ CPP and Cargo } & Detection and guided surgery of cancer \\
\hline 1 & Activatable CPPS (ACPPs) & Cancer including metastases & $\begin{array}{c}\text { Activation of flourascent ACCP by cell specific } \\
\text { proteases }\end{array}$ \\
\hline 2 & Conjugates of RGD-peptides & Tumours & Targetting integrin subtypes $\alpha$ v $\beta 3, \alpha 4 \beta 1, \alpha 3$ \\
\hline 3 & Ratiometric activatable CPP & Thyroid carcinoma & Detection of residual tumor after thyroidectomy \\
\hline 4 & Ratiometric activatable CPP & Squamous cell carcinoma & Early detection of oral cancer by flourescence ilumi- \\
\hline 5 & $\begin{array}{c}\text { MMP-2 activatable CPP and integrin } \\
\alpha v \beta 3 \text { ligand }\end{array}$ & Glioblastoma & Tumor imaging and flourescence-guided surgery \\
\hline 6 & Ratiometric activatable CPP & Pancreatic cancer & flourescence-guided surgery \\
\hline 7 & Activatable CPP-dendrimer-Gd & Detection of small tumor in rodent models & Imaging of tumors by magnetic resonance at 3 Tesla \\
\hline 8 & \multicolumn{2}{|c|}{ Retina diseases } & Retina diseases \\
\hline
\end{tabular}


Selective transport of cargoes into an organ seems to be quite more difficult as selective transport into a cell line or tissue. The group of Brock has critically reviewed the current status of renal targeting drugs. In a very recent publication Collado Camps and Brock [59] critically reviewed a lot of papers regarding distribution of CPPs or CPP-bearing particles in different organs. They could show that in many cases the concentration of CPPs in target tissue is low compared to other organs like liver, kidneys, or lungs. Thus, they recommend studying the bio distribution on an organ level in the early beginning of developing CPP-derived drugs.

\section{Conjugation to Polymers, Dendrimers, Liposomes and Nanoparticles}

With the aim of improving pharmacokinetic parameters and of easy handling certain CPPs were coupled to polymers, dendrimers, liposomes, and nanoparticles. These complex structures allow a stricter navigation to the target cells by coupling of additional affinity ligands, such as selective antibodies, ligands for membrane receptors or other binding proteins on the surface of target cell. Aiming for further enhancing target selectivity the method of dual and multifold targeting was developed, leading to so-called multifunctional pharmaco-nanoparticles. They can be derived from very different chemical structures. Some examples are shown in Table 3.

Conjugation of CPPs to polymers, copolymers dendrimers or nanoparticles is a strongly increasing research field in the last decade. But this covalent binding of CPPs and ligands for therapeutically requires special polymers. Because in most cases drugs have to be applied for a long time period the biocompatibility of the polymer supports must be tested. This means that the polymers, dendrimers, and nanoparticles should be not only biocompatible, but also immunologically inert, what seems to be difficult to achieve. If the polymers and the peptides are inert, it has to be demonstrated that also the linker moieties to CPPs or ligands are immunologically inert. The polymer should be either completely stable over a long time period or should be completely degraded to non-toxic basic structures. Table 3 lists the polymers with different basic structures. Independently on their chemical and pharmacological properties the way of these particles from place of administration to target tissue and their elimination should be studied thoroughly. This includes uptake into and metabolism in blood cells, too. The polymers, dendrimers and nanoparticles should be sized for leaving the blood vessels about the target tissue; they must be optimized regarding right size and a flexible architecture to flow through vessels-leaks.

Liposomes are already used for many decades. They allow encapsulation of drugs, which means shielding from degradation and enabling transport through membranes. CPPs at the surface on liposomes make the transport more selective and target directed. Vladimir Torchilin started with insertion of CPPs into outer surface of liposomes and created the pharma-liposomes [60,61]. Nevertheless, of certain difficulties in handling of liposomes their application gives the advantage for combining different target navigation systems for enhancing the selectivity of transport.

Nanoparticles are formed from different chemical basic structures, including gold suspensions, silicon carriers and aggregates from certain polymers or oligomers [62-64]. They have to be biocompatible and have to allow conjuga- tion of different molecules. The particle size should be between 60 and $150 \mathrm{~nm}$. In certain cases, toxicity of nanoparticles can be independent on their chemical structure.

\section{Application for Imaging Diseased Tissues}

CPPs can be also used for imaging of diseased tissues. Detecting primary tumors in a very early stage strongly improves the chances of successful therapy. Thus, structures from Swiss army pocketknife type were used for detecting colon-, breast-, pancreatic cancer, squamous cell carcinoma and thyroid carcinoma. For diagnostic use the CPPs can be coupled to sensitive markers, like NIR-fluorescence markers, NMR-sensitive Gd-complexes, or radionuclide. Imaging with cell-selective and labeled CPPs allows not only detecting tumors, metastases, thrombosis or inflammations but also the complete removal of diseased tissue by guided surgery through visualizing the margin between healthy and diseased tissue [65].

\section{Preclinical and Clinical Studies}

As discussed in the introduction a huge number of publications about CPPs which has appeared in the last two decades are concerned to pharmaceutical tasks, contain animal experiments, and some of them clinical trials, too. In their review Guidotti et al. [2] list 28 clinical trials with corresponding NCT registration. Few of the trials are already in phase 3 . It is commonly accepted that the process of developing a drug, from inception through the first experiments followed by animal experiments and clinical testing, can take on average more than twenty years. Thus, on this 30th birthday of the CPPs it is not unexpected that no one compound is approved as drug by the FDA. The huge number of research papers reflect the high promises of a therapeutically use. CPPs open not only new therapeutic possibilities but also can enhance efficiency and selectivity of already existing drugs. Based on their functional properties CPPs can be used for penetration of barriers, for killing of microorganisms and for treatment of diseases through internalization of effective drugs into target tissue.

\section{Antimicrobial activity}

Due to their action on biomembranes certain CPPs exert directly antimicrobial activities. They can act against bacteria, fungi, viruses, and protozoa or they can transport antibiotics into infected cells [66]. Results obtained with CPPs are very promising mainly for resistant bacteria and difficult to treat fungi, $[67,68]$. Use of certain CPPs against such viruses as Herpes simplex opens new therapeutic possibilities [69]. Certain CPPs show some potential for drug development even in the fight with such worldwide distributed diseases as malaria or visceral leishmaniasis. Preclinical trials in corresponding animal models and clinical trials are listed in Tables 5 and 6.

\section{Stroke, inflammation, pain}

Aiming to reduce infarct size and to support the recovery different CPPs are used to deliver such compounds into myocardial cells which are influence signal pathways. The internalization of ligands for protein binding domains, inhibitors or activators of protein kinases and other enzymes helps to treat stroke, infarct, and different kinds of pain. Transport of heat shock proteins [70], an inhibitor protein of NFKB [71] and the protein p53 is applied to treat mainly inflammation processes. Thus, delivery of the anti-apoptotic peptide BH4 


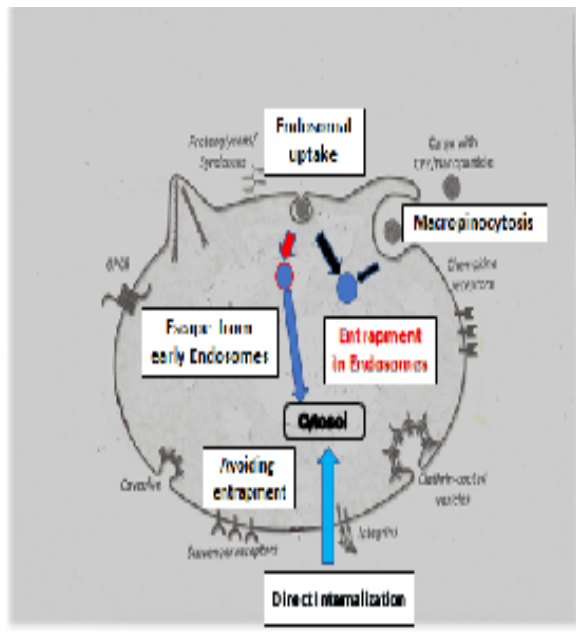

Figure 2. Avoiding entrapment in endosomes and triggering escape from endosomes.

Endosomal uptake leads in most cases to entrapment in endosomes. Functional sequences or certain sequence properties help to escape. Direct uptake through cell membrane transports directly into cytosol or subcellular organelles.

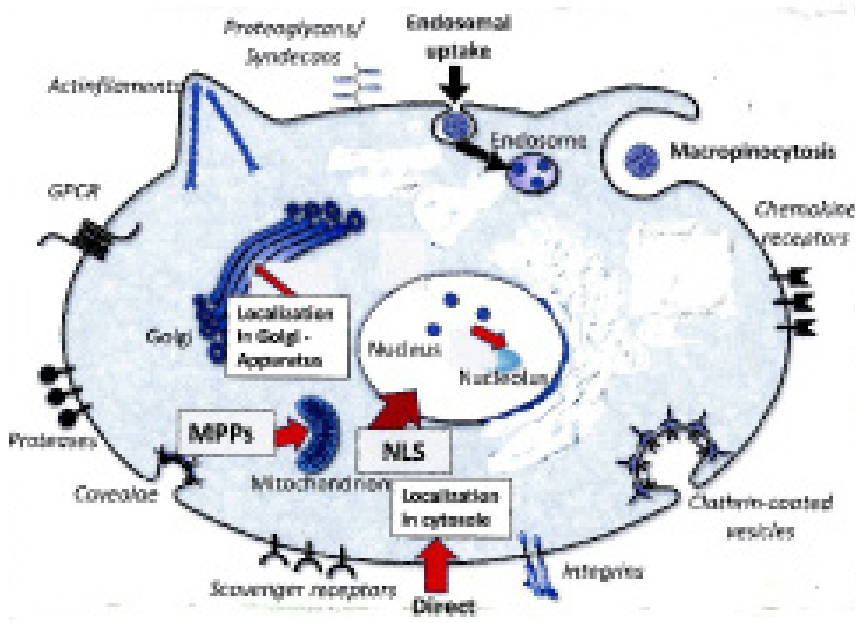

Figure 4. Transport into subcellular organelles.

Transport into Cytosole, Endosomes, Nucleus, Nucleolus, Mitochondria, Golgi Apparatus. NLS: Nuclear localization sequence; MPPs: Mitochondria penetrating peptides.

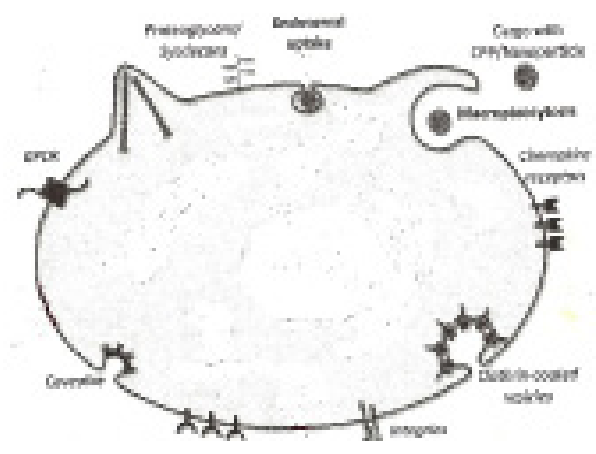

Figure 3. Surface of a target cell with uptake receptors and elements. Scavanger receptors, Syndecans, Chemokine receptors, Integrin receptors, G-protein-coupled receptors (GPCRs), and structural elements (Caveolae, Clathrin, endocytosis and macropinocytosis) are involved in uptake mechanism.

Table 5. Transport of antimicrobial cargoes into infected cells.

\begin{tabular}{|c|c|}
\hline \multicolumn{2}{|c|}{ Combination of CPP with antimicrobial Cargo } \\
\hline $\begin{array}{c}\text { CPP-Morpholino oligonucleotide } \\
\text { conjugate }\end{array}$ & $\begin{array}{c}\text { Antisense technology to treat } \\
\text { multi-resistant bacteria }\end{array}$ \\
\hline $\begin{array}{c}\text { CPP-antisense oligonucleotide } \\
\text { conjugate }\end{array}$ & $\begin{array}{c}\text { Activity against multi-resistant } \\
\text { bacteria }\end{array}$ \\
\hline $\begin{array}{c}\text { Complexex of Schiff base with Eu/ } \\
\text { Tb formed with CPPs }\end{array}$ & $\begin{array}{c}\text { Activity against Pseudomonas } \\
\text { aeroginosa and Salmonella typh- } \\
\text { imurium }\end{array}$ \\
\hline $\begin{array}{c}\text { HIV-TA(47-58) with D-amino acids } \\
\text { complexed with trypsin }\end{array}$ & $\begin{array}{c}\text { Anti-microbial activity } \\
\text { Octaarginine complexed with Cipro- } \\
\text { floxazin derivatives }\end{array}$ \\
$\begin{array}{c}\text { Enhancenent of antibacterial activ- } \\
\text { ity of Ciprofloxazin }\end{array}$ \\
\hline
\end{tabular}

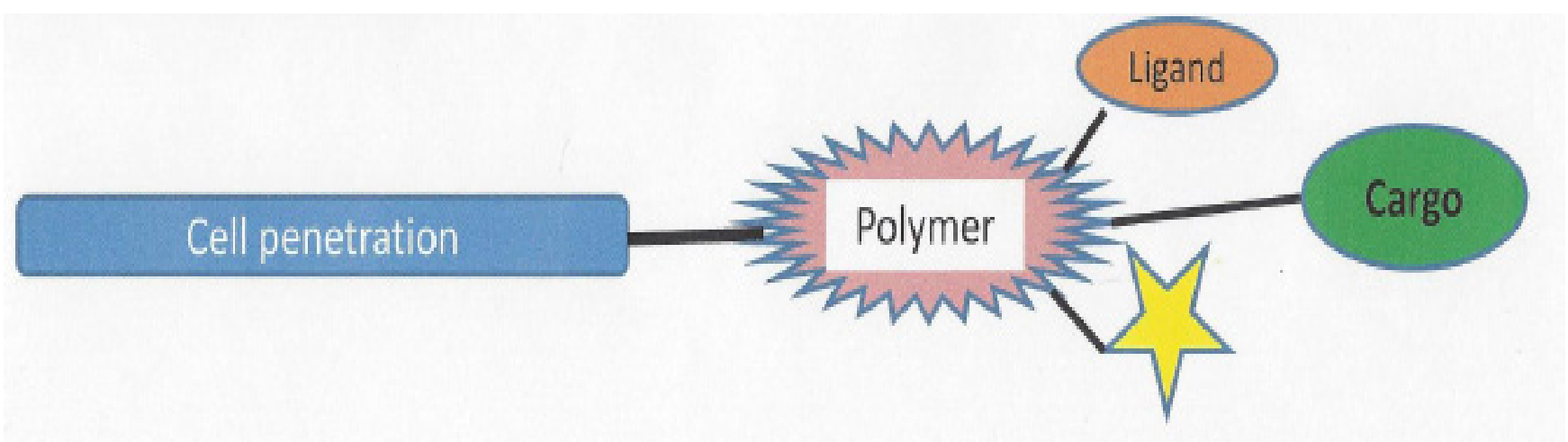

Figure 5. Enhanced possibilities for directed transport through polymer binding. 
prevents cardiac ischemia-reperfusion injuries [72]. Inhibiting intracellular kinases by inhibitors which are conjugated to HIV-TAT protect the ischemic heart [73]. CPPs mediated delivery of therapeutic molecules also protects against cerebral ischemia and reduce the pain in the central nervous system [74].

\section{Muscular disease Duchenne}

Duchenne, a genetically based muscular disease, is till now difficult to treat. Successful attempts were undertaken to correct the faulty splicing of RNA from muscle protein dystrophin. Derivatives of nucleic acids such as peptide-nucleic acids (PNAs) and morpholino oligonucleotides (Mos) either covalently coupled to CPPs or non-covalently complexed with suitable CPPs open a door to treat this disease. In particular, the application of splice correcting morpholino oligonucleotides (SCONs) aids in the treatment of Duchenne muscular dystrophy [75]. Very successful trials with most sophisticated CPPs were undertaken by the group from Ü. Langel [76].

\section{Treatment of Glioblastoma}

The ability of certain CPPs to penetrate the blood-brain barrier (BBB) $[77,78]$ allows to undertake preclinical and human clinical trials to treat the glioblastomas. This treatment leads to considerable size reduction of the tumor $[79,80]$. Furthermore, with help of penetration the BBB also neuropathic pain can be treated. Cationic CPPs are used for delivering anti-inflammatory compounds into cells aiming treatment of rheumatoid arthritis $[81,82]$

Because CPPs are able to penetrate also other barriers like, skin, mucosa and conjunctiva of eye they are able to avoid administration of drugs by painful injections with needles. Their replacement by non-invasive crèmes containing CPPs seems to be very convenient. Even oral applications of CPP-bearing drugs were successfully performed. Many attempts were undertaken to administrate insulin without needles [83]. Not unexpectedly, the number of registered trials for cosmetic use of CPPs, for needleless administration of botulinum toxin, exceeds the number of trials in other application fields.

\section{Therapy of eye diseases}

Therapy of eye diseases plays an important role by in vivo experiments with animals and clinical application of CPPs. Eyes are surrounded by conjunctiva, have in front the cornea and inside the lens, the glass body, and the retina. Therapies are required for cornea, lens and especially for retina. Till now many drugs are administrated by often repeated injections. CPPs could allow the administration by dropping conjugates formed from drugs and CPPs. As well as inner cornea, lens and retina are achievable with CPPs [84]. Thus, cataract and macula-degeneration possibly can be treated in future with help of CPPs and without injection into the eyes. It has been shown that CPPs are able to penetrate the ocular barrier without impairing its biological function $[79,80]$.

\section{Treatment of different kinds of tumors}

Very most preclinical and clinical trials were performed for treatment of different kinds of tumors. The aim of cancer therapy is according to Bitler and Schröder to destroy invasive carcinoma without "sacrificing the patient's quality of life" [87]. CPPs help to transport into tumor cells such classical anti-cancer drugs like cis-platin, doxorubicin, paclitaxel, vimentin or compounds of classical chine's medicine. This is important because until now the efficient intracellular delivery of anti-cancer drugs like organometallic compounds is an important focus in clinical research. Since CPPs from first generation only help to increase the intracellular amount of anti-cancer drug in many cell types, tumor-specific CPPs from the newer generation and activatable CPPs deliver the drugs selectively into cancer tissues, such helping to avoid site actions on all types of fast regenerating tissues as mucosa or hairs. From the new generation of CPPs the natively tumour specific peptides like protamine, crotamine, azurin, peptide CB5005, buffalo cathelicidin, spider toxin Lycosin-I, maurocalcine, buforins, and PepFect peptides), are of special interest. For highly specific targeting of cancer cells, protease-activatable LMWP derivatives have been developed [88]. They help to target drug-resistant breast cancer and enables drug delivery to the brain through intranasal administration $[80,88]$.

From the tumour specific enzymes Azurin and Oncogenase very effective CPPs could be developed, which have been used for selective tumour killing. In summary it can be concluded that tissue selective CPPs can be used for very selective treatment with coupled drugs. Some CPPs act synergistic with chemotherapeutics or enhance sensitivity of tumor tissue to these drugs [89]

Preclinical studies were performed besides with covalent conjugates between CPPs and cargoes by the non-covalent strategy, too. Thus Bonnet et al. Internalized inhibitors of cyclin-dependent kinases [90] and siRNA targeting cyclin B1 in mouse tumour models. In particular, the formation of non-covalent complexes of cationic CPPs with highly selective inhibiting RNAs promises significant potential in the fight against cancer diseases [28].

\section{Gene Therapy}

Gene therapy is the transfer of functional and therapeutic genetic material such as plasmid DNA (gene transfer), siRNA, shRNA and miRNA for gene modulation or of nucleases for gene editing. In contrast to the uptake of proteins and drugs, the transfer of native DNA and plasmids is considerably more difficult. In vitro and in animal experiments genes could be successfully internalized and expressed. In contrast to DNA, certain RNA types and oligonucleotide mimics of RNA have been successfully internalized. They are applied for blocking hepatic metastases, the treatment of resistant tumors, muscular dystrophy and infections with resistant bacteria. Using protamine as a component of a multifunctional vector, also He et al. [91] transfected tumor cells with CRISPR-Cas9 plasmid to modulate the properties these cells. Nevertheless, transfection with DNA and plasmids remains crucial for many therapeutic purposes, such as, the treatment of cardiovascular diseases, including those used to avoid of heart transplantations, and treatment for cystic fibrosis. However, using CPPs in the clinic, the stable integration of genes into the genome remains far from achievable at this stage.

\section{Vaccination with CPPs}

The recent situation with SARS-CoV-2 pandemic gives rise to discuss application of CPPs for development of vaccines. The use of CPPs for generating vaccines against cancer was described in various publications [92-94]. Mainly the group of Bolhassani was involved in that research [review 95]. They describe for instance in original publications the use of a DNA-vaccine 
against human papilloma virus (HPV) type 16 induced cancer. Because HPV E7 oncogene is constantly expressed by HPV infected tumor cells and by all pre-cancerous cells, this oncogene is an ideal target for tumor specific immunotherapy. For internalization of DNA into antigen presenting cells MPG-peptides can be used [28]. Internalization of negatively charged DNA or RNA requires an about tenfold molar excess of positively charged CPPs. In the recent pandemic situation vaccines are required for all people in the world. It means that for an RNA-vaccine oligonucleotides must be prepared in an amount of some hundred kilograms but CPPs are necessary in a tenfold higher amount. Because both compounds, nucleic acids and peptides respectively, have to be prepared and synthesized in high purity for clinical use. It seems to be impossible to generate such an amount in a very short time. The syntheses of few metric tons CPPs require not only highly sophisticated equipment but also chemists with much experience.

Despite of the expected advantages by complex formation with of CPPs compared to lipids in the BioNTech-Pfizer product the application of CPPs for vaccine generation cannot be recommended. It takes too long time and syntheses of CPPs are too expensive. Nevertheless, after succeeding with the pandemic situation the advantage and disadvantage of RNA for generating vaccines in a pandemic situation must be discussed thoroughly. In contrast to a lipid-complexed RNA-vaccine the preparation of viral vectors is a well-established process and allows an easy up scaling. RNA-CPP-vaccines or RNA-liposome-vaccines can be recommended only in the tumor therapy, because of the significant smaller number of patients. But generally, delivery of gene vaccine (DNA, pDNA or RNA, respectively) with CPPs for anti-cancer therapy remains a challenge for the near future.

\section{Comparison of CPPS to Other Methods of Cell Penetration}

Despite this minireview is focused on Cell-Penetrating Peptides it has to compare with other possibly methods of transport through membranes of living cells. For influencing intracellular signal-transduction via delivery of cargoes, such as peptides, proteins, nucleic acids, and drugs into live cells can be used a variety of chemical, mechanical, electrical, and biological methods, which are shortly explained below. These methods of cell-penetration are often described in the literature. They are very efficiently in the case of cells, cell-cultures, and tissues and can also help to internalize cargoes into difficult to transfect cells.

\section{Detergents}

Many different chemical detergents are commercially available. The amphipathic organic compounds disturb cell membranes and thereby allow uptake of compounds from extracellular space. CPPs are in most cases more effective in transporting the same cargoes than detergents, but they use similar mechanisms. Some detergents, for instance "Invivofectamine®", are described as biocompatible for in vivo experiments and applicable in the clinic, too. Another very interesting example is "Lipofectamine CRISPRMAX" which was characterized as best lipid nanoparticle for the delivery of Cas-9 RNPs into a variety of mammalian cell lines. A new direction consists in the application of natural detergents. Thus, mucins were used as multifunctional building blocks for delivery of drugs.

Polymers, Dendrimers, Nanoparticles
In many cases polymers from Table 3 are also applied without CPPs for transport of different cargoes. Thus, positively charged polyethylene-imine can be used for complexation of negatively charged nucleic acids to trigger uptake into cells [96,97]. Dextran based polymers are multifold used for internalization of different cargoes $[98,99]$ Even the very inflexible brush polymers can be used for cargo transport into dendritic cells [64].

\section{Magnetofection}

This method uses the magnetic power to bring cargoes into live cells $[100,101]$. This method is also used for drug delivery, even in the clinic. For magnetofection experiments the medium-dependent difference in cytotoxicity of the transfection-supporting agents is the limiting factor. By our experience, the concentration of polyethylene-imine (PEI)-covered magnetic beads strongly limits the application of magnetic beads because of their high cytotoxicity.

\section{Electroporation ("Electropermealization")}

Electroporation is the method of choice for internalization of very large, conformational inflexible and charged molecules, DNA, pDNA and different kinds of RNA [102] . Thus, in our studies to transfect Leishmania tarentolae with recombinant DNA the electro-permeabilization remained the only reasonable tool [46]. Neither detergents and polymers nor magnetofection or CPPs are able to achieve transfection of these cells.

According to Rols [103], internalization of plasmids during electroporation occurs through a multi-step mechanism. The plasma membrane is permeabilized facing the two charged electrodes. Increasing the transmembrane potential by an electrical field induces the formation of local "transiently permeable structures" that allow the exchange of molecules between the intracellular and extracellular compartment. The permeable membrane macrodomains seems to be large enough for the uptake of inflexible molecules with high molecular weight like DNA and plasmids.

\section{Viral Vectors}

Transfection of cells with help of various viruses or virus-vectors has been performed for many decades. Internalization of DNA, plasmids and RNA occurs with good efficiency, in some cases even into difficult to transfect cells. For in vitro research Adenoviruses, Turnip yellow mosaic virus [104], and often also Lenti-viruses are applied. A large variety of designed lentiviral particles is commercially available as "lentiviral solutions". Mainly cDNA, microRNA and shRNA were transported. But there exists a strong limitation in the clinic. The viral vectors have drawbacks such as immunogenicity, promiscuous tropism, and the inability to transfect certain types of cells.

But it seems that in many cases the CPPs are more promising and convenient for clinical use than chemical detergents, viral vectors and electrical or mechanical penetration methods. These methods can be taken in consideration for studies on cells, tissues and in some cases even animal experiments. For longtime clinical application they are mostly not applicable or only with very few exceptions.

The text above was written before pandemic disease SARS$\mathrm{CoV}-2$ attacks our world. Now I must revise my mind. Viral vectors belong to the good cure for this corona virus, because in a 
Table 6. Antimicrobial activity of CPPs.

\begin{tabular}{|c|c|c|}
\hline No. & $\begin{array}{l}\text { CPP without } \\
\text { Cargo }\end{array}$ & Anti-microbial activity \\
\hline \multicolumn{3}{|r|}{ Antibacterial Activity } \\
\hline 1 & $\operatorname{HIV-TAT}(47-58)$ & Staphylococcus aureus \\
\hline 2 & Pep-1 & Methicillin resistant Staphylococcus aureus \\
\hline 3 & $\begin{array}{l}\text { Crotamine deriva- } \\
\text { tive "CyloP-1" }\end{array}$ & $\begin{array}{l}\text { Representative pathogens ie Methicillin resis- } \\
\text { tant Staphylococcus aureus }\end{array}$ \\
\hline 4 & pVEC & Antibacterial activity \\
\hline 5 & TP10 & Neisseria Meningitidis \\
\hline 6 & Buforin & $\begin{array}{l}\text { Anti-Gram positive and anti-Gram negative } \\
\text { bacteria }\end{array}$ \\
\hline \multicolumn{3}{|r|}{ Antifungal Activity } \\
\hline 7 & Crotamine & antifungal \\
\hline 8 & Buforin & antifungal \\
\hline 9 & pVEC & Anti Candida albicans \\
\hline \multicolumn{3}{|r|}{ Antiviral Activity } \\
\hline 10 & Azurin & Anti-HIV infections \\
\hline 11 & $\begin{array}{l}\text { HIV-TAT, Pene- } \\
\text { tratin }\end{array}$ & $\begin{array}{l}\text { Inhibition of Herpes simplex virus entry into } \\
\text { cornea of eyes }\end{array}$ \\
\hline \multicolumn{3}{|r|}{ Anti-Protozoa Activity } \\
\hline 12 & Crotamine & Anti-plasmodium falciparum (Anti-Malaria) \\
\hline 13 & Azurin & Anti-plasmodium falciparum (Anti-Malaria) \\
\hline 14 & MPG-peptides & Protozoa mediated diseases \\
\hline 15 & Octaarginine & Anti-plasmodium falciparum (Anti-Malaria) \\
\hline 16 & MPG-peptides & Anti-Leishmania (Anti visceral leishmaniasis) \\
\hline
\end{tabular}

Table 7. Treatment of stroke, pain, muscle dystrophy, inflammation and wrinkles.

\begin{tabular}{|c|c|c|c|}
\hline No. & CPP and Cargo & Treated Disease & Effect \\
\hline \multicolumn{4}{|c|}{ Infarct } \\
\hline 1 & $\begin{array}{l}\text { HIV-TAT conjugated } \\
\text { to BH4-domain of anti- } \\
\text { apoptotic protein }\end{array}$ & $\begin{array}{c}\text { Cardiac isch- } \\
\text { emia-reperfusion } \\
\text { injuries }\end{array}$ & $\begin{array}{c}\text { Drastically reduc- } \\
\text { tion of infarct size } \\
\text { Reduction of infarct } \\
\text { size }\end{array}$ \\
\hline 2 & $\begin{array}{c}\text { HIV-TAT (47-57) } \\
\text { conjugated to PKCS in- } \\
\text { hibitor KAI-9803; NCT } \\
00093197\end{array}$ & $\begin{array}{l}\text { Myocardial } \\
\text { infarction }\end{array}$ & $\begin{array}{l}\text { Recovery of con- } \\
\text { tractile function }\end{array}$ \\
\hline 3 & $\begin{array}{l}\text { HIV-TAT (47-57) conju- } \\
\text { gated to PKCE activator }\end{array}$ & $\begin{array}{l}\text { Myocardial } \\
\text { infarction }\end{array}$ & $\begin{array}{l}\text { Recovery of con- } \\
\text { tractile function }\end{array}$ \\
\hline \multicolumn{4}{|c|}{ Central Nervous System and Pain } \\
\hline 4 & $\begin{array}{l}\text { HIV-TAT }(48-57) \text { conju- } \\
\text { gated to terminal kinase } \\
\text { binding motif }\end{array}$ & Cerebral ischemia & $\begin{array}{c}\text { Restoring cerebral } \\
\text { blood flow, block- } \\
\text { ing neuronal cell } \\
\text { death }\end{array}$ \\
\hline 5 & $\begin{array}{l}\text { Penetratin fused to } \\
\text { Cre-recombinase }\end{array}$ & $\begin{array}{c}\text { Neurodegenerative } \\
\text { diseases }\end{array}$ & $\begin{array}{c}\text { Genomic recombi- } \\
\text { nation of embryon- } \\
\text { ic and adult neural } \\
\text { tissues }\end{array}$ \\
\hline 6 & $\begin{array}{l}\text { HIV-TAT (47-57) conju- } \\
\text { gated to PKCE inhibitor }\end{array}$ & Pain & $\begin{array}{l}\text { Treatment of neuro- } \\
\text { pathic pain }\end{array}$ \\
\hline \multicolumn{4}{|c|}{ Muscle Dystrophy } \\
\hline 7 & $\begin{array}{l}\text { Conjugates of CPPs } \\
\text { to phosphor-diamidate } \\
\text { morpholino oligomers }\end{array}$ & $\begin{array}{c}\text { Duchenne muscu- } \\
\text { lar dystrophy }\end{array}$ & $\begin{array}{l}\text { Splice correction } \\
\text { leading to restore } \\
\text { dystrophin }\end{array}$ \\
\hline & \multicolumn{3}{|c|}{ Inflammation and Immune System } \\
\hline 8 & $\begin{array}{c}\text { HIV-TAT coupled to IkB } \\
\text { protein }\end{array}$ & $\begin{array}{l}\text { Rheumatoid arthri- } \\
\text { tis (mouse model) }\end{array}$ & $\begin{array}{c}\text { Blocking of joint } \\
\text { swelling and ery- } \\
\text { threma }\end{array}$ \\
\hline 9 & $\begin{array}{l}\text { (Arg)8 conjugated to } \\
\text { Cyclosporin A }\end{array}$ & Psoriasis & $\begin{array}{l}\text { Reduced secretion } \\
\text { of pro-inflammato- } \\
\text { ry cytokines }\end{array}$ \\
\hline \multicolumn{4}{|c|}{ Therapy with Botox } \\
\hline 10 & $\begin{array}{c}\text { HIV-TAT(49-57) conju- } \\
\text { gated to Botulinum toxin } \\
\text { Type A }\end{array}$ & $\begin{array}{c}\text { Excessive sweat- } \\
\text { ing wrinkles }\end{array}$ & $\begin{array}{c}\text { Temporarily } \\
\text { blocking of neuro- } \\
\text { muscular synaptic } \\
\text { transmission }\end{array}$ \\
\hline
\end{tabular}


Table 8. Penetration of Blood-Brain-Barrier.

\begin{tabular}{|c|c|c|c|}
\hline No & CPP & Cargo & Effect \\
\hline \multicolumn{4}{|c|}{ BLOOD-BRAIN-BARRIER } \\
\hline 1 & HIV-TAT conjugated to & $\begin{array}{c}\text { Inhibitor of cJun N- terminal kinase } \\
\text { (JNK) }\end{array}$ & Protection against cerebral ischemia \\
\hline 2 & HIV-TAT & Bcl-xL & Protection against ischemic brain injury \\
\hline 3 & HIV-TAT, Penetratin fusionated to & Cre-recombinase & Studies in neural development and neurophysiology \\
\hline 4 & Elastin-like polypeptide fusionated to & Myc inhibitory polypeptide & Treatment of rat glioma model \\
\hline 5 & CPPs conjugated to nanoparticles & Doxorubicin & Treatment of glioblastomas \\
\hline & Fragments and analogs of CB5005 & Doxorubicin & Treatment of glioblastomas \\
\hline 6 & PepFect 14 and PepFect 18 & $\begin{array}{c}\text { Conjugated or formation of non-cova- } \\
\text { lent complex to siRNA }\end{array}$ & Treatment of glioblastomas \\
\hline 7 & Oligoarginines (Arg) 8 conjugated & to Neuromedin $\mathrm{U}$ & Memory improvement in mice \\
\hline 8 & HIV-TAT(47-57) conjugated & to PKCE inhibitor & Treatment of neuropathic pain \\
\hline
\end{tabular}

Table 9. Penetration of skin, mucosa and intestinal tissue.

\begin{tabular}{|c|c|c|c|}
\hline No & CPP & Cargo & Effect \\
\hline \multicolumn{4}{|c|}{ SKIN } \\
\hline 1 & HIV-TAT & Fluorescent nanoparticles & Translocation of nanoparticles int deeper skin layers \\
\hline 2 & CPPs & Nano-particles & \\
\hline 3 & HIV-TAT(49-57) conjugated to & Botulinum toxin Type A & Treatment of sweating and wrinkles \\
\hline 4 & $\begin{array}{l}\text { Cross-linked new synthetic peptide } \\
\text { carrier/ ovalbumine condensate }\end{array}$ & $\begin{array}{l}\text { Redox-sensitive disulfide bond } \\
\text { to Vaccine }\end{array}$ & Subcutaneous vaccination \\
\hline \multicolumn{4}{|c|}{ INTESTINAL ABSORPTION AND TRANSPORT THROUGH MUCOSA } \\
\hline 5 & $\begin{array}{c}\text { Disulfide conjugate with oligoarginine } \\
\text { (Arg), }\end{array}$ & Triptolide & Treatment of rheumatoid arthritis, psoriasis and leukemia \\
\hline 6 & Oligoarginine- modified nanoparticles & Insulin & Non-invasive insulin delivery \\
\hline 7 & Optimized CPP sequence & Insulin & Non-invasive insulin delivery \\
\hline
\end{tabular}


Table 10. Therapy of eye-diseases.

\begin{tabular}{|c|c|c|}
\hline CPP and Cargo & Eye Disease & Effect \\
\hline $\begin{array}{c}\text { HIV-TAT conjugated to Protein } \\
\text { p53 }\end{array}$ & $\begin{array}{c}\text { Retinoblastoma level of tumor cell apoptosis } \\
\text { eyes }\end{array}$ \\
\hline -calpain C2L domain peptide & Retinitis pigmentosa & Protection against photoreceptor cell death \\
\hline Penetratin & Eye diseases & Noninvasive intraocular drug delivery \\
\hline CPPs conjugated to nanoparticle & Blindness by mices & Penetration of cornea \\
\hline Elasn-like polypeptide & Diseases of cornea & Anti-VEGF drugs \\
\hline Coupling of drugs to CPPs & Makula degeneration & Degradation of conformational changed proteins in lenses \\
\hline a.B- Crystallin with CPPs
\end{tabular}

Table 11. Application of CPPs in the therapy of tumors.

\begin{tabular}{|c|c|c|c|}
\hline No & CPP or CPP and cargo & Treated cancer & Action \\
\hline 1 & HIV-TAT fused to heat shock protein gp96 & Cancer and infectious diseases & Stimulation of T-cell response \\
\hline 2 & $\begin{array}{l}\text { HIV-TAT coupled to degradation domain (ODD) } \\
\text { of HIF-1a }\end{array}$ & Rodent malignant ascites tumor & $60 \%$ cure rate in other-wise lethal model cancer \\
\hline 3 & CPPs conjugated to organometallio compounds & Different kinds of cancer & $\begin{array}{c}\text { Internalization of anticancer drugs like organometal } \\
\text { conjugates, cis-Platin }\end{array}$ \\
\hline 4 & HIV-TAT conjugated to CIGB-300 & Cancer (cervical malignancies) & Induction of apoptosis \\
\hline 5 & Oligoarginines conjugated to vindoline derivatives & Leukemia tumor-bearing mices & Inhibition of tumor growth \\
\hline 6 & $\begin{array}{l}\text { Non-covalent complexes of CPPs with inhibitors } \\
\text { of cyclin-dependent kinase }\end{array}$ & Breast-Cancer & Inhibition of proliferation \\
\hline 7 & $\begin{array}{l}\text { Non-covalent complex of amphipathic peptide } \\
\text { MPG-8 with siRNA targeting cyclin B1 }\end{array}$ & Cancer & Reduction of tumor growth \\
\hline 8 & $\begin{array}{l}\text { Non-covalent complex of CADY-1 with doxoru- } \\
\text { bicin }\end{array}$ & Cancer & $\begin{array}{l}\text { Extended blood residence time and increased intracellu- } \\
\text { lar concentration }\end{array}$ \\
\hline 9 & Polyglutamic acid-integrin-paclitaxel & Cancer & Blocking of cell migration and capillary tube formation \\
\hline 10 & CB5005 conjugated to Doxorubicin & Glioma U87 & High affinity to brain, Inhibition of tumor growth \\
\hline 12 & Protamine & Breast cancer & Overcoming drug resistance \\
\hline 13 & Crotamine & Melanoma (mouse model) & \\
\hline 14 & Crotamine conjugated gold particles & & Anti-cancer Drug \\
\hline 15 & Azurin p28 & & Acts as inhibitor of $\mathrm{p} 53$ ubiquitination \\
\hline 16 & Azurin p28 & Glioblastoma & \\
\hline 17 & Azurin p28 & & Patients with advanced solid tumors \\
\hline 18 & Azurin (96-113) & & Inhibition of tumor growth \\
\hline
\end{tabular}


pandemic situation a vaccine must be prepared very fast. Since preparation of viral factors occurs in aqueous buffer solution and can be upscaled very easily, whereas the synthesis of CPPs must performed on the solid phase, requires special equipment, specialists with many experiences and is more expensive. In the case of vaccination viral vectors are administrated in low concentration and only twice a year. Under these special conditions viral vectors exert a sufficient low toxicity and are applicable.

\section{Outlook: self navigating pharmaco-carriers}

Cell- and tissue specific Cell-penetrating Peptides are potent agents in diagnostic and therapy of diseases because they can internalize bioactive compounds and labels into live target cells as well as in animals and humans. That internalization is important either for stable imaging or stimulating and blocking intracellular pathways. The discussed results show that certain very promising fields for application of CPPs could be found. By my opinion not only the most important but also the most promising fields for application are the treatment of infarct, neurodegenerative diseases, muscle dystrophy, inflammation, thrombosis, and different kinds of cancer: cervix, breast, prostate, melanoma, thyroidal, pancreatic.

Furthermore, based on their antimicrobial activity and the supported transport of nucleic acids and antibiotics into infected cells the application of CPPs can help to treat resistant or multi-resistant bacteria.

Due to their capability to penetrate barriers CPPs can be used to replace repeated injections by painless, safe, and needleless kinds of administration. Despite DNA and plasmids as cargoes are often successful transported into cell cultures, but most clinical applications were proven as unsuccessfully. Thus, the classical gene-therapy with DNA seems to be far away from a general clinical use. Because many genetic diseases require replacement of wrong by healthy genes the efforts in clinical application of gene-therapy should be intensified. Detection of tumors and small-sized metastases requires highly selective CPPs, coupling of highly sensitive labels and use of highly sensitive detection methods such as NIR-fluorescence scanning and sensitive NMR tomography.

Future research should be focused on such diseases for which other therapies failed, on improvement of classical drugs by tissue specific delivery into cells or cell organelles and on transport of drugs through blood-brain-barrier and into cornea, lens, and retina of eyes. The application of subcellular organelle-specific peptides, like mitochondria penetrating peptides could enable to treat organelle evoked diseases. As an aimed endpoint should be in our focus the development of self-navigating biocompatible nanoparticles for drug delivery into target tissue.

\section{References}

1. Reissmann S. Cell-penetration: scope and limitations by application of cell-penetrating peptides. J Pept Sci. 2014;20:760-784.

2. Guidotti G, Brambilla L, Rossi D. Cell-penetrating peptides: From basic research to clinic. Trends in Pharmacological Sci. 2017;38(4):408-424.

3. Silva S, Almeida AJ, Vale N. Combination of cell-penetrating peptides with nanoparticles for therapeutic application: A Review 2019; Biomolecules. 9(22):doi:10.3390/biom9010022.
4. Kardani K, Milani A, Shabani SH, et al. Cell penetrating peptides: the potent multi-cargo intracellular carriers. Expert Opinion Drug Delivery. 2019;16(11):1227-1258.

5. Kurrikoff K, Langel U. Recent CPP-based applications in medicine. Expert Opinion on Drug Delivery 2019;16(11):1183-1191.

6. Repke A, Bienert M. Mast cell activation - a receptor independent mode of substance P action. FEBS Lett. 1987;221:236-240.

7. Frankel AD, Pabo CO. Cellular uptake of the TAT protein from human immunodeficiency virus. Cell. 1988; 55: 189-1193.

8. Joliot A, Pernelle C, Deagozini-Bastin H, et al. Antennapedia homeobox peptide regulates neural morphogenesis. ProcNatlAcadSci USA. 1991; 88: 1864-1868.

9. Olson ES, Aguilera TA, Jiang T, et al. In vivo characterization of activatable cell-penetrating peptides for targeting protease activity in cancer. Integr. Biol. 2009; 1: 382-393.

10. Bidwell GL, Raucher D. Application of thermally responsive polypep tides directed against c-Myc transcriptional function of cancer therapy. Mol Cancer Ther. 2005;4(7):1076-1085.

11. Keller AA, Mussbach F, Breitling R, et al. Relationships between cargo, cell penetrating peptides and cell type for uptake of non-covalent complexes into live cells. Pharmaceuticals. 2013; 6:184-203.

12. Chakrabarty AM. Bacterial azurin in potential cancer therapy. Cell Cycle. 2016;15(13):1665-1666.

13. Byun Y, Singh VK, Yang VC. Low molecular weight protamine: a potential non-toxic heparin antagonist. Thromb Res. 1999;94(1): 53-61.

14. Radis-Baptista G, Kerkis I. Crotamine, a small basic polypeptide myotoxin from rattlesnake venom with cell-penetrating properties. Cur Pharmaceutical Design. 2011;17(38):4351-4361.

15. Radis-Baptista G, de la Torre BG, Andreu D. A novel cell-penetrating peptide sequence derived by structural minimization of a snake toxin exhibits preferential nucleolar localization. J Med Chem. 2008;51 (22):7041-7044.

16. Tansi FL, Filatova MP, Dmitri O, et al. New generation CPPs show distinct selectivity for cancer and non-cancer cells. J Cell Biochem. 2019;120:6528-6541.

17. Fajloun Z, Kharrat R, Chen I, et al. Chemical synthesis and characterization of maurocalcine, a scorpion toxin that activates $\mathrm{Ca}(2+)$ release channel/ryanodine receptors. FEBS Lett. 2000;469 (2-3):179-185.

18. Tisseyre C, Bahemberae E, Dardevet L, et al. Cell-penetration properties of a high efficient mini-maurocalcine peptide. Pharmaceuticals. 2013;6(3):320-339.

19. Cho Jh, Sung BH, Kim SC. Buforins: Histone H2A-derived antimicrobial peptides from toad stomach. Biochim Biophys Acta 2009;1788:1564-1569.

20. Lim KJ, Sung BH, Shin JR, et al. A cancer specific cell-penetrating peptide BR2, for the efficient delivery of an $\mathrm{scFv}$ into cancer cells. Plos One. 2013;6(6):e66084.

21. Zhang L, Zhang Y, Tai L, et al. Functionalized cell nucleus-penetrating peptide combined with doxorubicin for synergistic treatment of glioma. Acta Biomaterialia. 2016;42:90-101.

22. Neundorf I, Rennert R, Hoyer J, et al. Fusion of a short HA2-derived peptide sequence to cell-penetrating peptides improves cytosolic uptake, but enhances cytotoxic activity. Pharmaceuticals. 2009;2:49-65. 
23. Xu YY, Cao XW, Fu LY, et al. Screening and characterization of a novel high-efficiency tumor-homing cell- penetrating peptide from the buffalo cathelicidin family. J Pep Sci. 2019;25(9):e3201.

24. Tan H, Huang Y, Xu J, et al. Spider peptide lycosin-I functionalized gold nanoparticles for in vivo tumor targeting and therapy. Theranostics. 2017;7(12):3168-3178.

25. Regberg J, Shrimanee A, Erlandsson M, et al. Rational design of a series of novel amphipathic cell-penetrating peptides. Int J Pharma- ceutics. 2014;464(1-2):111-116.

26. Ervin EH, Pook M, Teino I, et al. Targeted gene silencing in human embryonic stem cells using cell- penetrating peptide PepFect 14. Stem Cell Res Therapy. 2019;10(43).

27. Chaloin L, Vidal P, Heitz A, et al. Con- formations of primary amphipathic carrier peptides in membrane mimicking environments. Biochemistry. 1997; 36: 11179-11187.

28. Crombez L, Morris MC, Dufort S, et al. Targeting cyclin B1 through peptide-based delivery of siRNA prevents tumor growth. Nucleic Acid Res. 2009; 37: 4559-4569.

29. Lin YZ, Yao SY, Veach RA, et al. Inhibition of nuclear translocation of transcription factor NF-kappa B by a synthetic peptide containing a cell-permeable motif and nuclear localization sequence. J Biol Chem. 1995; 270: 14255-14258.

30. Liu KY, Timmons S, Lin YZ. Hawiger J Identification of a functionally important sequence in the cytoplasmic tail of integrin beta 3 by using cell-permeable peptide analogs. Proc Natl Acad Sci USA. 1996; 93: 11819-1824.

31. Rennert R, Wespe C, Beck-Sickinger AG, et al. Developing novel hCT derived cell-penetrating peptides with improved metabolic stabil- ity. Biochim Biophys Acta. 2006; 1758: 347-354.

32. Chakrabarty AM, Bernardes N, Fialho AM. Bacterial proteins and peptides in cancer therapy: Today and tomorrow. Bioengeneered. 2014;5(4):234.

33. Jia L, Gorman GS, Coward LU, et al. Preclinical pharmacokinetics, metabolism, and toxicity of azurin p-28 (NSC745104) a peptide inhibitor of p53 ubiquitination. Cancer Chemotherapy and Pharmacol. 2011;68(2):513-524.

34. Taylor BN, Mehta RR, Yamada T, et al. Noncationic peptides from Azurin preferentially enter cancer cells. Cancer Res. 2009;69(2):537-546.

35. Bernardes N, Ribeiro AS, Abreu S, et al. The bacterial protein azurin impairs invasion of FAK/Src signaling in P-cadherin-overexpressing breast cancer cell models. PLOS One. 2013;8(7):e69023.

36. Warso MA, Richards JM, Mehta D, et al. A first-in-class, first-in human, phase I trial of Azurin p28, a non-HDM2-mediated peptide inhibitor of $\mathrm{p} 53$ ubiquitnation in patients with advanced solid tumors. Brit J Cancer. 2013;108:1061-1070.

37. Chaudhari A, Mahfouz M, Fialho AM, et al. Cupredoxin-cancer interrelationship: azurin binding with EphB2, interference in EphB2 tyrosine phosphorylation, and inhibition of cancer growth. Biochemistry. 2007;46:1799-1810.

38. Bernardes N, Chakrabarty AM, Fialho AM. Engeneering of bacterial strains and their products for cancer therapy. Appl Microbiol Biotechnol. 2013;97: 5189-5199.

39. Ma Y, Gong C, Ma Y, et al. Direct cytosolic delivery of cargoes in vivo by a chimera consisting of $\mathrm{D}$ - and $\mathrm{L}$-arginine residues. $\mathrm{J}$ Control Rel. 2012;162(2):286-294.
40. Yamada T, Signorelli S, Cannistraro S, et al. Chiral- ity switching with an anionic cell-penetrating peptide inhibits translocation without affecting preferential entry. Mol Pharm. 2015;12(1): 140-149.

41. Schneider AFL, Wallabregue ALD, Franz L, et al. Targeted subcellular protein delivery using cleavable cyclic cell- penetrating peptides. Bioconjug Chem. 2019;30(2):400-404.

42. Del'Guidice T, Lepetit-Stoffaes JP, Bordeleau LJ, et al. Membrane permeabilizing amphiphilic peptide delivers recombinant transcription factor and CRISPR-Cas9/Cpf1 ribonucleoproteins in hard to modify cells. PlosOne. 2018;13(4):e0195558.

43. Hazzan T, Guhl S, Artuc M, et al. An efficient method for gene knock- down by RNA interference in human skin mast cells. Exp Dermatol. 2017;26(11):1136-1139.

44. Goding SR, Basse PH. Genetic engineering of natural killer cells. In: Lotze MT, Thomson AW, eds. Natural Killer Cells. 2010:633-644.

45. Keller AA, Maess MB, Schnoor M, et al. Transfecting macrophages. In: Rousselet (ed.), Macrophages: Methods and Protocols, Methods in Molecular Biol. 2018;1784:187-195.

46. Keller AA, Scheiding B, Breitling R, et al. Transduction and transfection of difficult-to-transfect cells: Systematic attempts for the transfection of protozoa Leishmania. J Cell Biochem. 2019;120:14-27.

47. Oh D, Nasrolahi Shirazi A, Northup K, et al. Enhanced cellular uptake of short polyarginine peptides through fatty acylation and cyclization. Mol Pharm. 2014;11(8):2845-2854.

48. Reichart F, Horn M, Neundorf I. Cyclization of cell-penetrating peptide via click-chemistry increases proteolytic resistance and improves delivery. J Pept Sci. 2016; 22: 421-426.

49. Nikura K, Horisava K, Doi N. Endosomal escape efficiency of fusiogenic B18 and B55 peptides fused with EGFR single chain Fv as estimated by nuclear translocation. J Biochem. 2016;159(1):123132.

50. Diao Y, Han W, Zhao H, et al. Designed synthetic analogs of the $\alpha$-helical peptide temporin-La with improved antitumor efficacies via charge modification and incorporation of the integrin $\alpha v \beta 3$ homing domain. J Pep Sci. 2011;18:476-486.

51. Tansi FL, Rüger R, Böhm C, et al. Potential of activatable FAPtargeting immunoliposomes in intraoperative imaging of spontaneous metastases. Biomaterials. 2016;88:70-82.

52. Andreev OA, Engelman DM, Reshetnyak YK. pH-sensitive membrane peptides (pHLIPs) as a novel class of delivery agents. Mol Membrane Biol. 2010;27(7):341-352.

53. Splith K, Bergmann R, Pietzsch J, et al. Specific targeting of hypoxic tumor tissue with nitroimidazole-peptide conjugates. ChemMedChem. 2012;7(1):57-61.

54. Fu A, Zhao Z, Gao F, et al. Cellular uptake mechanism and ther apeutic utility of a novel peptide in targeted delivery of proteins into neuronal cells. Pharm Res. 2013;30(8):2108-2117.

55. Van der Brand D, Veelken C, Massuger L, et al. Penetration in 3D tumor spheroids and explants: Adding a further dimension to the structure-activity relationship of cell-penetrating peptides. Bioch Biophys Acta (Biomembranes). 2018;1860:1342-1349.

56. Yousif LF, Stewart KM, Horton KL, et al. Mitochondria-penetrating peptides: sequence effects and model cargo transport. ChemBioChem 2009; 10: 2081-2088.

57. Pille J, van Lith SAM, van Hest JCM, et al. Self-assembling VHH- 
elastin-like peptides for photodynamic nanomedicine. Biomacromolecules. 2017;18(4):1302-1310.

58. Qiu Y, Yu Q, Shi K, et al. Cell-penetrating peptides induce apotosis and necrosis through specific mechanisms and cause impairment of $\mathrm{Na}+-\mathrm{K}+$-ATPase and mitochondria. Amino Acids. 2017;49:75-88.

59. Collado Camps E, Brock R. An Opportunistic route to success: Towards a change of paradigm to fully exploit the potential of cell-penetrating peptides. Bioorg Med Chem. 2018;26(10):27802787.

60. Torchilin VP. Tat peptide-mediated intracellular delivery of pharmaceutical nanocarriers. Adv. Drug Deliv Rev. 2008;60:548-558.

61. Deshpande P, Jhaveri A, Pattni B, et al. Transferrin and octaarginine modified dual-functional liposomes with improved cancer cell targeting and enhanced intracellular delivery for the treatment of ovarian cancer. Drug Del. 2018;25(1):517-532.

62. Xia H, Gu G, Hu Q, et al. Activatable cell penetrating peptide-conjugated nanoparticles with enhanced permeability for site-specific targeting delivery of anti-cancer drug. Bioconjugate Chem. 2013;24(3):419-430.

63. Leer Liu L, Dong X, Zhu D, et al. TAT-LHRH conjugated low molecular weight chitosan as a gene carrier specific for hepatocellular carcinoma cells. Int J Nanomed.2014;9:2879-2889.

64. Bühler J, Gietzen S, Reuter A, et al. Selective uptake of cylindrical poly(2 oxazoline) brush-antiDEC205 antibody-OVA antigen conjugates into DEC-positive dendritic cells and subsequent T-cell activation. Chem Eur J. 2014;20:12405-12410.

65. Tsien R, Malone CD, Olson ES, et al. Tumor detection at 3 Tesla with an activatable cell penetrating peptide dendrimer (ACPPD-Gd), at T1 Magnetic Resonance (MR) molecular imaging agent. PloS One. 2015;10(9):e0137104/1-e0137104/15.

66. Purkayastha N, Capone S, Beck AK, et al. Antibacterial activity of enrofloxacin and ciprofloxacin derivatives of $\beta$-octaarginine. Chemistry and Biodiversity. 2015;12(2):179-193.

67. Eriksson OS, Geoerg M, Sjoelinder H, et al. Identification of cell-penetrating peptides that are bactericidal to Neisseria meningitidis and prevent inflammatory responses upon infection. Antimicrobial Agents Chemotherapy. 2013;57:3704-3712.

68. Kynicki J, Milosavljevic V, Jelinkova P, et al. Europium and terbium Schiff base peptide complexes as potential antimicrobial agents against Salmonella typhimurium and Pseudomonas aeruginosa. Chemical papers. 2018; 72:1437-1449.

69. Akkarawongsa R, Cullinan AE, Zinkel A, et al. Corneal toxicity of cell-penetrating peptides that inhibit Herpes simplex virus entry. $\mathrm{J}$ Ocular Pharmacol Ther.2006;22(4):279-289.

70. Dietz G. Cell-penetrating peptide technology to deliver chaperones and associated factors in diseases and basic research. 2010; Current Pharmaceutical Biotechnol. 11: 167-174.

71. Orange JS, May MJ. Cell penetrating peptide inhibitors of nuclear factor-kappa B. Cell Mol Life Sci. 2008;65:3564-3591.

72. Boisguerin P, Red-Clouet C, Franck-Miclo A, et al. Systemic delivery of BH4 anti-apoptotic peptide using CPPs prevents cardiac ischemia-reperfusion injuries in vivo. J Contr Rel. 2011;156:146153.

73. Inagaki K, Hahn HS, Dorn GW, et al. Additive protection of the ischemic heart ex vivo by combined treatment with $\delta$-protein kinase $\mathrm{C}$ inhibitor and $\varepsilon$-protein kinase $\mathrm{C}$ activator. Circulation 2003;108:869-875.

74. Zou LL, Ma JL, Wang T, et al. Cell-penetrating peptide-mediated therapeutic molecule delivery into central nervous system. Current Neuropharm. 2013;11:197-208.

75. Moulton HM, Moulton JD. Morpholinos and their peptide conjugates: Therapeutic promise and challenge for Duchenne muscular dystrophy. Biochim Biophys Acta (Biomembranes). 2010;1798:2296-2303.

76. Andaloussi S, Lehto T, Lundin P, et al. Application of PepFect peptides for the delivery of splice-correcting oligonucleotides. Methods in Mol Biol 2011;683 (Cell-Penetrating Peptides):361-373.

77. Oller-Salvia B, Sanchez-Navarro M, Giralt E, et al. Blood-brain barrier shuttle peptides: an emerging paradigm for brain delivery. Chem Soc Rev. 2016;45:4690-4707.

78. Garcia J, Arranz-Gibert P, Sanchez-Navarro M, et al. Peptide shuttle-mediated delivery for brain gene therapies. Cur Topics in Med Chem. 2020;20(32):2945-2958.

79. Fialho AM, Salunkhe P, Manna S, et al. Glioblastoma multiforms: novel therapeutic approaches. ISRN Neurol.2012; Article ID $642345,10$.

80. Xia H, Gao X, Gu G, et al. Low molecular weight protamine-functionalized nanoparticles for drug delivery to the brain after intranasal administration. Biomaterials. 2011;32(36):9888-9898.

81. Hu X, Zhang M, Leak RK, et al. Delivery of neurotherapeutics across the blood brain barrier in stroke. Current Pharm. Design. 2012;18:3704-3720.

82. Cao G, Pei W, Ge H, et al. In vivo delivery of Bcl-xL fusion protein containing the TAT protein transduction domain protects against ischemic brain injury and neuronal apoptosis. J Neurosci. 2002;22: 5423-5431.

83. Guo F, Ouyang T, Peng T, et al. Enhanced oral absorption of insulin using colon-specific nanoparticles co-modified with amphiphilic chitosan derivatives and cell-penetrating peptides. Biomaterial Sci. 2019;7(4):1493-1506.

84. Pescina S, Ostacolo C, Gomez-Monterrey LM, et al. Cell penetrating peptides in ocular drug delivery: State of the art. J Control Rel. 2018;284:84-102.

85. Binder C, Read SP, Cashman SM, et al. Nuclear targeted delivery of macromolecules to retina and cornea. J Gene Med. 2011;13(3):158-170.

86. Pescina S, Sala M, Padula C, et al. Design and synthesis of new cell-penetrating peptides: Diffusion and distribution inside the cornea. Mol Pharmaceutics 2016;13(11):3876-3883.

87. Bitler BG, Schroeder JA. Anti-cancer therapies that utilize cell penetrating peptides. Recent Patents on Anti-Cancer Drug Discovery. 2010;5: 99-108.

88. Wang H, Zhao Y, Wang H, et al. Low-molecular-weight protamine-modified PLGA nanoparticles for overcoming drug-resistant breast cancer. J Control Rel. 2014;192:47-56.

89. Hu J, Wang J, Chen P, et al. HIV-TAT peptide immunoconjugates differentially sensitize breast cancer cells to selected anti-proliferative agents that induce the cyclin-dependent kinase inhibitor p21WAF-1. Bioconjug Chem. 2006;17:1280-1287.

90. Bonnet J, Scheper J, Divita G, et al. Targeting kinases and phosphatases that regulate cell cycle progression. Trends in Cell Cycle 
Res. 2008;183-208.

91. He H, Ye J, Liu E, et al. Low molecular weight protamine (LMWP): A nontoxic protamine substitute and effective cell-penetrating peptide. J Control Rel. 2014;193:63-73.

92. Saleh T, Bolhassani A, Shojaosadati SA, et al. MPG-based nanoparticle: An efficient delivery system for enhancing the potency of DNA vaccine expressing HPV16E7.Vaccine. 2015;33:3164-3170

93. Grau M, Walker PR, Derouazi M. Mechanistic insight into the efficacy of cell penetrating peptide-based cancer vaccines. Cellular Mol Life Sci. 2018;75(16):2887-2896.

94. Derouazi M, Di Berardino-BessonW, Belnoue E, et al. Novel cell penetrating peptide-based vaccine induces robust $\mathrm{CD} 4+$ and CD8+ T cell-mediated antitumor immunity. Cancer Res. 2015;75(15):3020-3031.

95. Bolhassani A, Safaiyan S, Rafati S. Review: Improvement of different vaccine delivery systems for cancer therapy. Molecular Cancer. 2011;10:3.

96. Ochrimenko S, Vollrath A, Tauhardt L, et al. Dextran-graft-linear poly(ethylene imine)s for gene delivery: importance of the linking strategy. Carbohydrate Polymers. 2014; 113:597-605.

97. Fischer D, Osburg B, Petersen H, et al. Effect of poly(ethylene imine) molecular weight and pegylation on organ distribution and pharmacokinetics of polyplexes with oligodeoxynucleotides in mices. Drug Metab Dispos. 2004;32:983-992.

98. Alibolandi M, Alabdollah F, Sadeghi F, et al. Dextran-b-poly(lactide-co-glycolide) polymersome for oral delivery of insulin: In vitro and in vivo evaluation. J Control Rel. 2016; 227:58-70.

99. Becker B, Englert S, Schneider H, et al. Multivalent dextran hybrids for efficient cytosolic delivery of biomolecular cargoes. J Pep Sci. 2021; e3298.

100. Krötz F, Wit C, Sohn HY, et al. Magnetofection a highly efficient tool for antisense oligonucleotede delivery in vitro and in vivo. Mol Ther. 2003; 7 (5 pt. 1): 700-710.

101. Ensenauer R, Hartl D, Vockley J, et al. Efficient and gentle siRNA delivery by magnetofection. Biotech Histrochem. 2011; 86:226231.

102. McCoy AM, Collins ML, Ugozzoli LA. Using the gene Pulser MXcedll electroporation system to transfect primary cells with high efficiency. J Vis Exp. 2010;35;6. pp.

103. Rols MP. Electropermeabilization, a physical method for delivery of therapeutic molecules into cells. Biochim Biophys Acta. 2006;1758:423-428.

104. Kim E-S, Yang S-W, Hong D-K, et al. Cell-penetrating DNA-binding protein as a safe and efficient naked DNA delivery carrier in vitro and in vivo. Biochem Biophys Res Commun. 2010;392:9-15.

To cite this article: Siegmund Reissmann. State of Art: Cell Penetration and Cell-Penetrating Peptides and Proteins. Health Education and Public Health. 2021; 4:2.

(C) 2021 Reissmann S. 